\title{
湖北金沙河水库浮游植物群落结构及其与水环境因子的关系
}

\author{
张 云, 马徐发 ${ }^{*}$, 郭飞飞, 李建柱, 熊邦喜 \\ (华中农业大学水产学院,武汉 430070)
}

\begin{abstract}
摘 要: 为探明长江中游大型水库水质状况, 并为饮用水源安全保障提供科学依据, 于 2013-2014 年按季节对湖北红安 金沙河水库浮游植物群落结构及其多样性进行调查, 并运用多元统计定量分析浮游植物群落结构与环境因子之间的关 系. 共鉴定出浮游植物 8 门 94 属 216 种, 其中绿藻门为优势种群, 其种类数占总物种数的 $51.39 \%$, 其次是硅藻门和蓝藻 门. 金沙河水库优势种随季节变化而变化, 夏季以尖针杆藻 (Synedra acus) 的优势度最大 $(0.195)$, 秋季以小胶鞘藻 (Phormidium tenus) (0.180) 和中华尖头藻 (Raphidiopsis sinensia) (0.171) 的优势度最大, 冬季以具星小环藻 (Cyclotella stelligera ) (0.220) 和圆筒雉囊藻 (Dinobryon cylindricum) (0.234) 的优势度最大, 春季则是链状曲壳藻 (Achanthidum catenatum) 成为绝对优势种 $(0.910)$; 金沙河水库浮游植物群落总的变化规律为夏季的硅藻门、蓝藻门和绿藻门, 秋季的蓝藻门、绿 藻门、硅藻门和隐藻门, 向冬季的硅藻门和金藻门转变, 春季则是硅藻门为绝对优势类群. Shannon-Wiener 多样性指数和 Pielou 均匀度指数显示, 浮游植物在秋季的多样性和均匀度较高, 春季的多样性指数和均匀度指数显著低于其它季节, 这 是因为春季有绝对单一的优势物种, 而秋季没有, 且秋季的物种数最多, 因此其 Margalef 丰富度指数也最高. 将各季节优 势种和经 Pearson 相关性分析笁选出的环境因子进行冗余分析, 结果表明笁选的环境因子中磷酸盐、总磷和溶解氧浓度是 影响金沙河水库浮游植物群落结构的主要环境因子. 从藻类季节变化规律来看, 金沙河水库夏、秋季水质污染程度较春、 冬季严重;但从藻类丰度和多样性指数来看,春、夏季水质较秋、冬季污染严重.
\end{abstract}

关键词: 金沙河水库;浮游植物; 群落结构;环境因子;攵余分析

\section{Community structures of phytoplankton and their relationships with environmental factors in the Jinshahe Reservoir, Hubei Province}

\author{
ZHANG Yun, MA Xufa, GUO Feifei, LI Jianzhu \& XIONG Bangxi \\ (College of Fisheries, Huazhong Agricultural University, Wuhan 430070, P. R. China)
}

\begin{abstract}
In order to evaluate the water quality of drinking water resource in the middle reaches of the Changjiang River, phytoplankton community structures and their diversities were investigated seasonally from August, 2013 to April, 2014 in the Jinshahe Reservoir, Hubei Province. Meanwhile, multivariate statistics was used to analyze the relationships between phytoplankton assemblages and environmental variables. The results showed that there were total of 216 species of phytoplankton belonging to 8 phyla and 94 genera. Chlorophyta which made up of $51.39 \%$ of the total numbers of the species was the dominant group, followed by Bacillariophyta and Cyanophyta. Dominant species varied in different seasons. In summer, the ecological dominance of Synedra acus was the highest (0.195), and in autumn, Phormidium tenus (0.180) and Raphidiopsis sinensia (0.171) had the highest ecological dominance. In winter, Cyclotella stelligera (0.220) and Dinobryon cylindricum (0.234) had the highest ecological dominance, and Achanthidum catenatum was the absolute dominant species with its ecological dominance of 0.910 . In general, Cyanophyta, Bacillariophyta and Chlorophyta were dominant groups in summer, and Cyanophyta, Bacillariophyta, Chlorophyta and Cryptophyta were dominant groups in autumn. Bacillariophyta and Chrysophyta were dominant groups in winter, and Bacillariophyta was the absolute dominant group in spring. Biodiversity indices showed that phytoplankton had higher values of the ShannonWiener diversity and the Pielou diversity in autumn, but the lowest values in spring because the absolute dominant species appeared in spring other than in autumn. In addition, the highest value of Margalef diversity occurred in autumn because of its larger number
\end{abstract}

* 湖泊水库养殖容量及生态增养殖技术研究与示范项目 (201303056) 资助. 2014-08-04 收稿;2014-12-18 收修 改稿. 张云(1989 ), 女, 硕士;E-mail:zhangyun0708@163.com.

** 通信作者;E-mail:xufama@ gmail. com. 
of species. Redundancy analysis was used to analyze the relationships between the dominant species in each season and the environmental factors filtered by Pearson correlation analysis. The results showed that phosphate, total phosphorus and water temperature were the main environmental factors that have influenced phytoplankton assemblages. The reservoir had worse water quality in summer and autumn than in spring and winter which impacted on the variations of dominant groups of phytoplankton in different seasons, and had worse water quality in spring and summer than in autumn and winter which impacted on the cell abundance and biodiversity indices.

Keywords: Jinshahe Reservior; phytoplankton; community structures; environmental factors ; redundancy analyses

浮游植物群落的种类组成和数量结构变化在水体中都有一定的规律, 其变化规律主要受相关生物和非 生物因子的影响 ${ }^{[1]}$. 浮游植物群落结构组成对环境变化具有指示作用; 反之,环境条件的改变也会影响浮游 植物群落结构组成 ${ }^{[2]}$. 一般而言, 水温和营养盐是影响浮游植物生长的重要环境因子 ${ }^{[3]}$. 藻类进行光合作 用、营养物质运输、转换的酶系统活性与温度直接相关, 因此温度对光合作用能力、呼吸速率和生长率都有 重要作用 ${ }^{[4]}$, 每种藻类都有其最适温度范围. 蓝藻能够适应高温水体, 而硅藻和金藻适应的温度较低, 易在 春季形成优势, 绿藻则易在中等温度下形成优势 ${ }^{[5]}$. 因此, 温度可以影响水体中浮游植物群落的季节变化. 浮游植物需要多种矿物营养来维持生长, 其中氮、磷是浮游植物生长所需的主要营养盐. 一般认为, 浮游植 物的变化趋势与水体中营养盐的变化趋势一致,水体中营养盐的增加会促进浮游植物的快速增长, 所以可 以将浮游植物的增加作为水体中营养盐增加的标志 ${ }^{[6]}$. 在武汉东湖的研究表明, 氮、磷浓度的持续上升导致 水体中浮游植物种群朝着易形成水华的蓝藻演替 ${ }^{[7]}$. 此外, 其它非生物因子包括溶解氧、光照、透明度、 $\mathrm{pH}$ 值 等都对浮游植物有一定影响. 生物因子主要指浮游动物和鱼类的牧食作用对浮游植物的影响. 在一个水体中, 浮游植物种类较多, 其群落结构与动态是多个环境因子在时间和空间序列上综合作用的结果, 如何认识特定 水体中浮游植物群落的组成与动态是一个相当复杂的问题 ${ }^{\left[{ }^{2}\right.}$. 探讨浮游植物与环境因素之间关系的统计方法 很多,例如回归分析、相关分析、群落排序与聚类等,其中多元统计 (如典范对应分析、冗余分析) 运用最为广 泛 $^{[9-12]}$. 多元统计把对应分析与多元回归结合起来, 每一步计算结果都与环境因子进行回归,并且结合多个环 境因子,在同一排序图上反映群落、物种与环境两两间的关系,包含的信息量大,结果明确直观.

金沙河水库 $\left(31^{\circ} 17^{\prime} \sim 31^{\circ} 23^{\prime} \mathrm{N}, 114^{\circ} 32^{\prime} \sim 114^{\circ} 35^{\prime} \mathrm{E}\right)$ 位于湖北省黄冈市红安县, 在倒水支流金沙河之 上,设计库容为 $1.787 \times 10^{8} \mathrm{~m}^{3}$, 集水面积 $108 \mathrm{~km}^{2}$, 平均水深 $12.53 \mathrm{~m}$, 是一座典型的丘陵分枝型水库. 该水 库是长江中游众多水库中的大型水库之一, 在集水区特征、水库形态、综合的功能等方面具有代表性,其不 仅是著名“将军县”红安县城的唯一饮用水源地,也是湖北省会城市武汉市的备用水源地. 建库以来水库从 未进行过施肥和投饲养鱼, 水质良好, 虽然其水质一直保持在国家地表水 II 类标准, 但其周边还是存在茧石 矿、养猪场、农村农业生产、化肥厂生产等污染问题,这些污染会导致水体氮、磷浓度增加,使得水体向富营 养化趋势发展, 甚至有使局部水体发生蓝藻水华的风险, 而多数蓝藻分泌的藻毒素或异味物质会危害人体 健康, 从而影响正常的供水 ${ }^{[13]}$. 然而, 目前对金沙河水库的研究多集中于水库中鱼类年龄、生长与繁殖等方 面 ${ }^{[14-16]}$, 对水质与鱼类覀料生物的研究较少. 本研究通过调查金沙河水库理化因子和浮游植物群落结构,评 估金沙河水库目前的水质状况, 通过探讨金沙河水库浮游植物群落结构与环境因子的关系,篮选出影响其 群落结构分布的关键性因子, 从而有针对性地控制某些关键因子的输人, 避免因澡类大量繁殖而导致水华 发生,为金沙河水库水生态环境保护与饮用水源安全保障提供科学依据.

\section{1 材料与方法}

\section{1 采样点设置与采样时间}

根据金沙河水库形态, 全库共设 8 个采样点 (图 1), 其中 S1 站点位于水库下游取水口(坝前), S6 站点 位于靠上游的一个暂养鱼类的网拦寄养库湾, 虚线代表此库湾在平水期与库区隔离形成独立的库湾, 用于 暂养鱼类; 在丰水期则与库区相通,形成一个整体. S5、S7 和 S2 站点分别设在位于水库上、中、下方的库湾, S4、S3 和 S8 站点分别设在位于水库上、中、下方的敞水区. 采样时间为 2013 年 8 月初(夏季)、2013 年 10 月 中旬 (秋季)、2014 年 1 月中旬 (冬季)和 2014 年 4 月中旬 (春季). 其中 2014 年 4 月份为枯水期,水库上游 干涸,没有对 S5、S6 站点进行采样. 


\section{2 样品采集与测定}

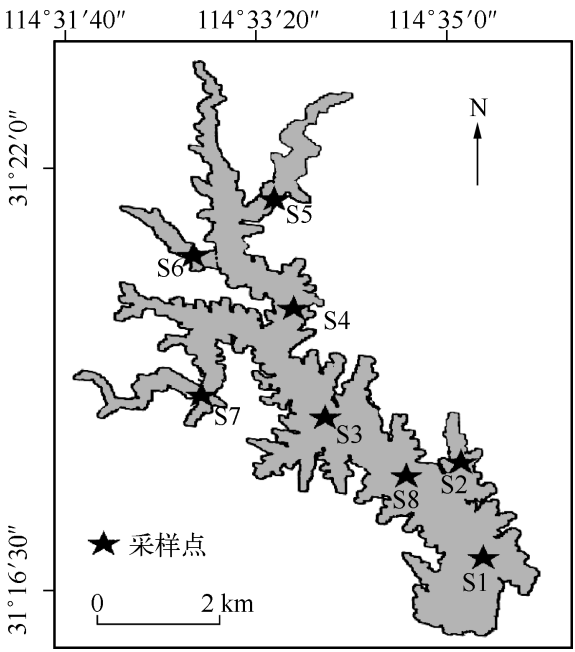

图 1 金沙河水库采样点分布

Fig. 1 Distribution of sampling sites in the Jinshahe Reservoir
浮游植物的调查研究方法参照《淡水浮游生物研究方 法 $\rangle^{[17]}$, 定性样品的采集使用 $25^{\#}$ 笁绢采集网, 在水面作 “ $\infty$ ” 字形拖曳, 将采得的样品收集在 $125 \mathrm{ml}$ 聚乙烯瓶中, 加福尔马林固定,使其最终浓度为 $4 \%$,带回实验室进行镜 检, 按文献 $[18]$ 鉴定到种. 定量样品使用 $5 \mathrm{~L}$ 有机玻璃采水 器采集, 采表层水 $1 \mathrm{~L}$, 加 $15 \mathrm{ml}$ 鲁哥试剂固定, 并带回实验 室经筒型分液漏斗静置沉淀 $48 \mathrm{~h}$, 吸去上清液,保留 $30 \mathrm{ml}$ 浓缩样品待检. 将样品充分摇匀后立即用移液枪吸取 $0.1 \mathrm{ml}$ 注人浮游植物计数框内, 轻轻盖上盖玻片, 用目镜视 野法在 $10 \times 40$ 倍显微镜下计数. 每瓶标本至少计数 2 片, 每片计数 $50 \sim 100$ 个视野, 同一样品的 2 次结果与平均数 之差不大于 $\pm 15 \%$ 即为有效结果, 取其平均值.

浮游植物由于个体小, 一般用细胞体积法来估算该种 藻类的生物量 $\left(10^{9} \mu \mathrm{m}^{3}=1 \mathrm{mg}\right)$. 为减少误差, 同一种类的 大型与小型个体要分别测量体积和计数.

计数结果与所采水样中浮游植物丰度的换算公 式 $^{[19]}$ 为:

$$
N=n_{i}\left[\frac{A}{A_{\mathrm{c}}} \cdot \frac{V_{\mathrm{s}}}{V_{\mathrm{a}}}\right]
$$

式中, $N$ 为原水样中的浮游植物总丰度, cells $/ \mathrm{L} ; A$ 为计数框面积, $\mathrm{mm}^{2} ; A_{\mathrm{c}}$ 为计数视野面积, $\mathrm{mm}^{2} ; V_{\mathrm{s}}$ 为 $1 \mathrm{~L}$ 原 水样沉淀浓缩后的体积, $\mathrm{ml} ; V_{\mathrm{a}}$ 为计数框的体积, $\mathrm{ml} ; n_{i}$ 为计数所得浮游植物的数目.

水体 DO 、水温 (WT) 和 $\mathrm{pH}$ 值采用 HACHHQ40d 便携式多参数水质分析仪 (美国) 现场测定. 总氮 (TN) 浓度采用碱性过硫酸钾消解, 紫外分光光度法测定; 铵态氮 $\left(\mathrm{NH}_{4}^{+}-\mathrm{N}\right)$ 浓度采用纳氏试剂比色法于波长 $420 \mathrm{~nm}$ 处测定; 硝态氮 $\left(\mathrm{NO}_{3}^{-}-\mathrm{N}\right)$ 浓度采用酚二磺酸分光光度法在 $410 \mathrm{~nm}$ 处测定; 亚硝态氮 $\left(\mathrm{NO}_{2}^{-}-\mathrm{N}\right)$ 浓度采 用 (N-1-荎基) 乙烯二胺比色法测定; 总磷 (TP) 浓度采用过硫酸钾消解, 钿锑抗比色法测定; 将采集的水样经 $0.45 \mu \mathrm{m}$ 混合纤维滤膜过滤后, 用锄锑抗比色法测定正磷酸盐 $\left(\mathrm{PO}_{4}^{3-}-\mathrm{P}\right)$ 浓度; 高锰酸盐指数 $\left(\mathrm{COD}_{\mathrm{Mn}}\right)$ 采用 酸性高镇酸钾法测定; 水样经 $0.45 \mu \mathrm{m}$ 醋酸纤维滤膜过滤后, 取滤膜反复冻融再以丙酮萃取, 用四色丙酮法 测定叶绿素a(Chl. a) 浓度 ${ }^{[20]}$.

\section{3 数据分析}

1.3.1 优势度和多样性指数的计算 优势度 $(Y)$ 计算公式为:

$$
Y=\frac{n_{i}}{N} \cdot f_{i}
$$

式中, $n_{i}$ 为第 $i$ 种的丰度, $f_{i}$ 为第 $i$ 种的出现率, $N$ 为总丰度. 把优势度 $Y \geqslant 0.02$ 的种类定为优势种 ${ }^{[21]}$.

浮游植物多样性指数采用 Shannon-Wiener 指数 $\left(H^{\prime}\right)$ :

$$
H^{\prime}=-\sum_{i=1}^{S} P_{i} \cdot \log _{2} P_{i}
$$

物种丰富度指数采用 Margalef 指数 $(D)$ :

$$
D=(S-1) / \log _{2} N
$$

物种均匀度指数采用 Pielou 指数 $(J)$ :

$$
J=H^{\prime} / \log _{2} S
$$

式中, $S$ 为样品中的种类总数, $P_{i}$ 为第 $i$ 个物种的丰度与样品总丰度的比值.

1.3.2 环境因子和浮游植物之间的关系 先对浮游植物物种数据作去趋势对应分析 (detrended correspon- 
dence analysis, DCA), 结果中 4 个轴中梯度最大值小于 3 , 因此本研究利用 CANOCO 4.5 软件, 采用线性模型 圥余分析 (redundancy analysis, RDA) 来解释浮游植物和环境因子之间的关系 ${ }^{[22]}$. 将 11 个环境因子做 Pearson 相关性分析, 删除与多个环境因子呈显著相关 $(P<0.05)$ 的环境因子和两个显著相关的环境因子中在空 间上变化较小的环境因子, 剩余的 7 个环境因子 $\left(\mathrm{NH}_{4}^{+}-\mathrm{N} 、 \mathrm{NO}_{3}^{-}-\mathrm{N} 、 \mathrm{PO}_{4}^{3-}-\mathrm{P} 、 \mathrm{TN} 、 \mathrm{TP} 、 \mathrm{COD}_{\mathrm{Mn}}\right.$ 和 DO $)$ 与物种优势 度 $Y \geqslant 0.02$ 的物种进行排序, 采用 Monte-Carlo 置换检验来确定环境变量的重要性及显著性 $(P<0.05)$. 为 了减小由数据方差差异过大而引起的误差, 排序物种密度经过 $\lg (x+1)$ 转换使数据呈正态分布 ${ }^{[11]}$. 图形绘 制在 Origin 8.0 和 CANODRAW 4.5 中完成.

\section{2 结果与分析}

\section{1 浮游植物群落特征}

2.1 .1 种类组成 调查期间, 金沙河水库共检出浮游植物 8 门 94 属 216 种, 其中绿藻门种类数最多, 有 111 种, 占总种 类数的 $51.39 \%$; 其次是硅藻门, 有 35 种, 占总种类数的 $16.20 \%$; 蓝藻门 33 种, 占总种类数的 $15.28 \%$; 裸藻门 23 种, 占总种类数的 $10.65 \%$; 金藻门、甲藻门、隐藻门和黄藻 门分别为 5 种、4 种、 4 种和 1 种, 分别占总种类数的 $2.31 \%$ 、 $1.85 \% 、 1.85 \%$ 和 $0.46 \%$.

从季节上来看, 浮游植物种类数秋季 $>$ 夏季 $>$ 春季 $>$ 冬 季(表 1 ).

2.1 .2 优势种 不同的季节浮游植物优势类群差异较大. 夏 季以蓝藻门、硅藻门和绿藻门为优势类群, 其中蓝藻门的优 势种类较多, 但以硅藻门的尖针杆藻 (Synedra acus) 的优势 度最大 $(0.195)$; 秋季以蓝藻门、硅藻门和隐藻门为优势类

表 1 金沙河水库浮游植物种类数

Tab. 1 Number of phytoplankton species in the Jinshahe Reservoir

\begin{tabular}{crrrr}
\hline 门类 & 夏季 & 秋季 & 冬季 & 春季 \\
\hline 蓝藻门 & 23 & 21 & 7 & 15 \\
绿藻门 & 59 & 80 & 50 & 54 \\
硅藻门 & 20 & 26 & 24 & 23 \\
裸藻门 & 7 & 21 & 6 & 7 \\
金藻门 & 4 & 4 & 2 & 4 \\
甲藻门 & 4 & 3 & 3 & 3 \\
隐藻门 & 1 & 3 & 3 & 4 \\
黄藻门 & 0 & 1 & 0 & 1 \\
总计 & 118 & 159 & 95 & 111 \\
\hline
\end{tabular}

群, 其中以蓝藻门的小胶鞘藻 (Phormidium tenus) (0.180) 和中华尖头藻 (Raphidiopsis sinensia) (0.171) 的优 势度最大; 冬季以硅藻门和金藻门丰度较高, 其中硅藻门的具星小环藻 (Cyclotella stelligera) (0.220) 和金藻 门的圆筒雉囊藻 (Dinobryon cylindricum) (0.234) 的优势度最大; 春季则以硅藻为优势门类, 并且硅藻门的链 状曲壳藻 (Achanthidum catenatum) 成为绝对的优势种, 其优势度高达 0.910 .

2.1 .3 丰度与生物量 浮游植物丰度的季节变化范围为 $7.99 \times 10^{5} \sim 360.20 \times 10^{5}$ cells/L, 平均丰度为 $111.32 \times 10^{5}$ cells $/ \mathrm{L}$, 其中 4 月最高, 1 月最低; 生物量的季节变化范围为 $0.7906 \sim 7.5478 \mathrm{mg} / \mathrm{L}$, 平均生物量 为 $4.2728 \mathrm{mg} / \mathrm{L}$, 其中 8 月最高, 1 月最低.

8 月蓝藻门的丰度最高, 为 $27.58 \times 10^{5} \mathrm{cells} / \mathrm{L}$, 占 8 月藻类总丰度的 $59.18 \%$, 其次是硅藻门和绿藻门, 分别占 8 月藻类总丰度的 $23.56 \%$ 和 $13.14 \% ; 10$ 月也是蓝藻门丰度最高, 为 $14.01 \times 10^{5}$ cells $/ \mathrm{L}$, 占 10 月藻 类总丰度的 $45.91 \%$, 其次是硅藻门 $(19.80 \%)$ 、绿藻门 $(17.57 \%)$ 和隐藻门 $(13.73 \%) ; 1$ 月丰度最高的是硅 藻门 $\left(3.15 \times 10^{5}\right.$ cells $\left./ \mathrm{L}\right)$, 占 1 月藻类总丰度的 $39.40 \%$, 其次是金藻门( $\left.27.70 \%\right)$ 和绿藻门 (26.64\%);4 月 硅藻门成为绝对优势类群, 其丰度为 $346.36 \times 10^{5} \mathrm{cells} / \mathrm{L}$, 占 4 月藻类总丰度的 $96.16 \%$. 生物量上,4 个季 节都是硅藻门的生物量最大, 其中 8 月和 4 月硅藻门生物量占绝对优势, 分别占相应月份藻类总生物量的 $75.21 \%$ 和 $86.98 \%, 10$ 月和 1 月硅藻门生物量分别占相应月份藻类总生物量的 $31.16 \%$ 和 57.21\% (图 2).

从空间分布来看, 8 月 S6 点的浮游植物丰度显著高于其它采样点,但其生物量最低,其它采样点丰度和 生物量之间没有显著差异; 10 月, 各采样点间藻类丰度和生物量均无显著差异, 1 月 S5 和 S7 样点的浮游植 物丰度和生物量均显著高于其它采样点, 4 月 S7 样点的藻类丰度显著高于其它采样点, 其生物量也是各采 样点中最高的 (图 3).

2.1 .4 浮游植物多样性 金沙河水库浮游植物 $H^{\prime}$ 值秋季最高 $(4.16)$, 春季最低 $(0.80) ; D$ 值秋季最高 (3.80), 冬季和春季相对较低 $(2.08) ; J$ 值冬季最高 $(0.67)$, 春季最低 $(0.14)($ 表 2$)$.

\section{2 水环境因子}

金沙河水库全年水温为 $5.8 \sim 33.2^{\circ} \mathrm{C}, \mathrm{pH}$ 值为 $7.20 \sim 8.69$, DO 为 $7.45 \sim 10.28 \mathrm{mg} / \mathrm{L}, \mathrm{NH}_{4}^{+}-\mathrm{N}$ 浓度为 


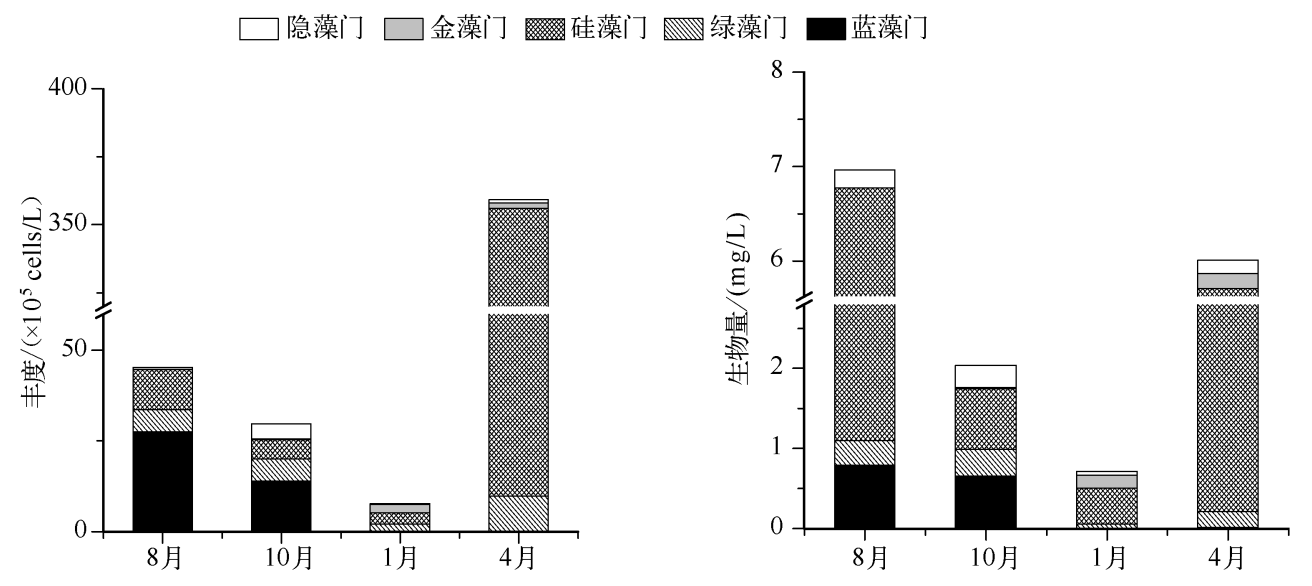

图 2 金沙河水库浮游植物优势门类丰度和生物量的季节变化

Fig. 2 The seasonal variations of abundance and biomass of dominate phyta in the Jinshahe Reservoir
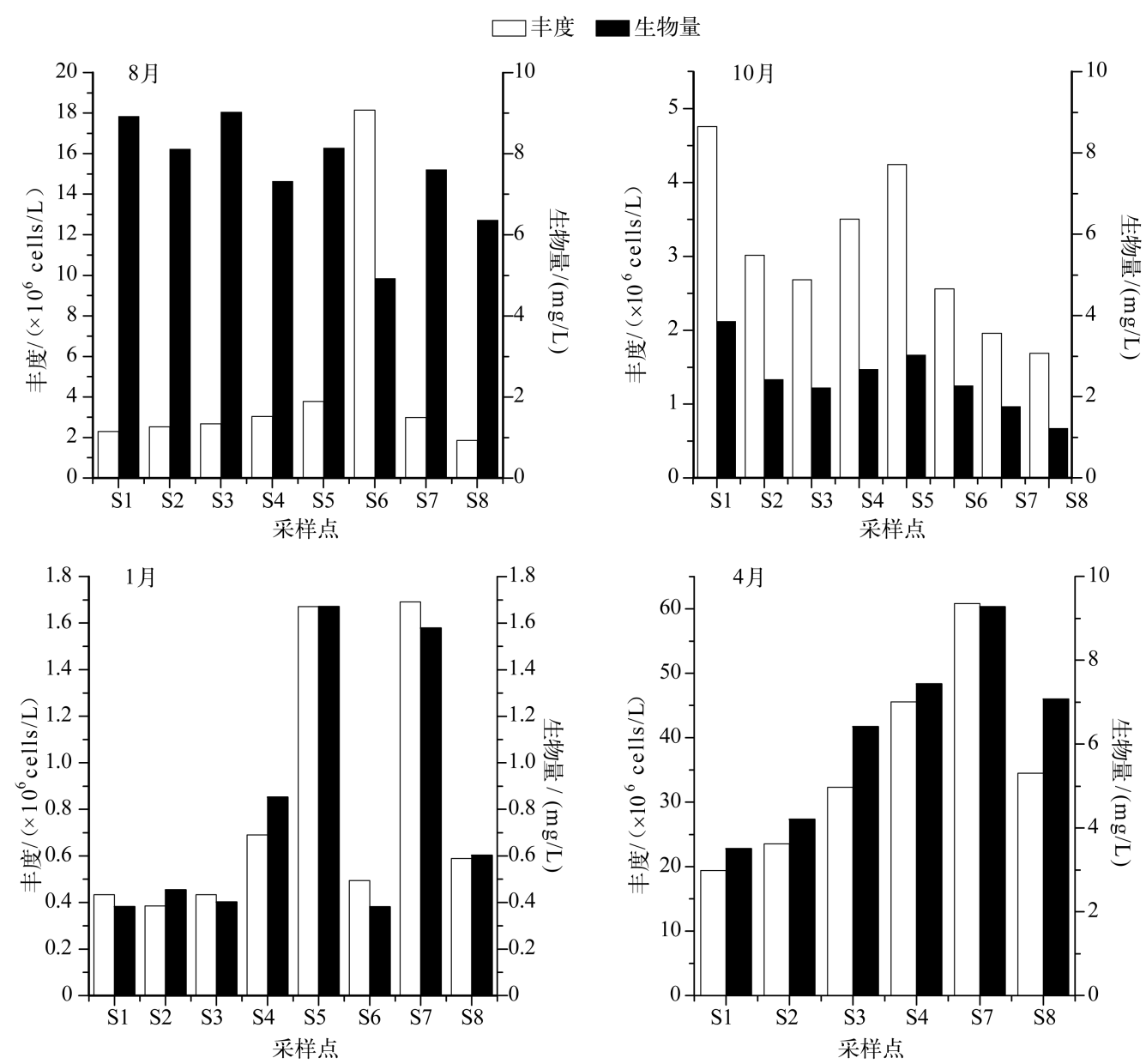

图 3 金沙河水库不同采样点浮游植物的丰度和生物量

Fig. 3 The abundance and biomass of phytoplankton at different sampling sites in the Jinshahe Reservoir 
$0.0173 \sim 0.6763 \mathrm{mg} / \mathrm{L}, \mathrm{NO}_{2}^{-}-\mathrm{N}$ 浓度为 $0 \sim$ $0.0057 \mathrm{mg} / \mathrm{L}, \mathrm{NO}_{3}^{-}-\mathrm{N}$ 浓度为 $0.0421 \sim$ $0.2968 \mathrm{mg} / \mathrm{L}, \mathrm{TN}$ 浓度为 $0.2167 \sim 0.9543$ $\mathrm{mg} / \mathrm{L}, \mathrm{PO}_{4}^{3-}-\mathrm{P}$ 浓度为 $0.0003 \sim 0.0222$ $\mathrm{mg} / \mathrm{L}$, TP 浓度为 $0.0040 \sim 0.0350 \mathrm{mg} / \mathrm{L}$, $\mathrm{COD}_{\mathrm{Mn}}$ 为 $0.6231 \sim 2.0625 \mathrm{mg} / \mathrm{L}, \mathrm{Chl}$. a 浓 度为 $0.0035 \sim 0.0197 \mathrm{mg} / \mathrm{L}$ (表 3 ).

\section{3 浮游植物群落结构与环境因子的关系}

表 2 金沙河水库浮游植物多样性

Tab. 2 Diversity of phytoplankton in the Jinshahe Reservoir

\begin{tabular}{ccccc}
\hline $\begin{array}{c}\text { 多样性 } \\
\text { 指数 }\end{array}$ & 夏季 & 秋季 & 冬季 & 春季 \\
\hline$H^{\prime}$ & $3.31 \pm 0.56$ & $4.16 \pm 0.45$ & $3.57 \pm 0.27$ & $0.80 \pm 0.12$ \\
$D$ & $2.63 \pm 0.35$ & $3.80 \pm 0.54$ & $2.08 \pm 0.38$ & $2.08 \pm 0.42$ \\
$J$ & $0.57 \pm 0.09$ & $0.65 \pm 0.07$ & $0.67 \pm 0.65$ & $0.14 \pm 0.02$ \\
\hline
\end{tabular}

经 RDA 分析,夏季,轴 1 和轴 2 所能 解释的物种比例为 $88.8 \%$, 影响浮游植物群落的主要环境因子是 $\mathrm{PO}_{4}^{3-}-\mathrm{P}$ 和 $\mathrm{DO}$ 浓度, 其中 $\mathrm{PO}_{4}^{3-}-\mathrm{P}^{\text {浓度的 }}$ 影响极为显著 $(P<0.01)$, 且与第 1 轴的相关性为 0.9434 , 说明第 1 轴基本可以反映 $\mathrm{PO}_{4}^{3-}-\mathrm{P}$ 浓度的变化梯 度. 夏季中华尖头藻丰度与 DO 浓度呈正相关, 阿氏颤藻 (Oscillatoria agardhii) 和小胶鞘藻丰度与 $\mathrm{PO}_{4}^{3-}-\mathrm{P}^{\text {浓 }}$ 度呈正相关, 土壤绿球藻 (Chlorococcum humicola)、水华微囊藻 (Microcystis flos-aquae) 和尖针杆藻丰度与多 数环境因子呈负相关 (图 4).

\section{表 3 金沙河水库全年水环境因子平均值}

Tab. 3 Average of aquatic environmental factors in the Jinshahe Reservoir

\begin{tabular}{|c|c|c|c|c|}
\hline 指标 & 夏季 & 秋季 & 冬季 & 春季 \\
\hline $\mathrm{NH}_{4}^{+}-\mathrm{N} /(\mathrm{mg} / \mathrm{L})$ & $0.1743 \pm 0.0431$ & $0.5039 \pm 0.1135$ & $0.0660 \pm 0.0416$ & $0.3384 \pm 0.1087$ \\
\hline $\mathrm{NO}_{2}^{-}-\mathrm{N} /(\mathrm{mg} / \mathrm{L})$ & $0.0002 \pm 0.0001$ & $0.0008 \pm 0.0003$ & $0.0042 \pm 0.0011$ & $0.0015 \pm 0.0011$ \\
\hline $\mathrm{NO}_{3}^{-}-\mathrm{N} /(\mathrm{mg} / \mathrm{L})$ & $0.1052 \pm 0.0791$ & $0.0840 \pm 0.0243$ & $0.1593 \pm 0.0269$ & $0.1068 \pm 0.0535$ \\
\hline $\mathrm{TN} /(\mathrm{mg} / \mathrm{L})$ & $0.7494 \pm 0.1219$ & $0.8417 \pm 0.0532$ & $0.2632 \pm 0.0453$ & $0.7401 \pm 0.0503$ \\
\hline $\mathrm{PO}_{4}^{3-}-\mathrm{P} /(\mathrm{mg} / \mathrm{L})$ & $0.0048 \pm 0.0023$ & $0.0152 \pm 0.0055$ & $0.0015 \pm 0.0007$ & $0.0073 \pm 0.0019$ \\
\hline $\mathrm{TP} /(\mathrm{mg} / \mathrm{L})$ & $0.0175 \pm 0.0109$ & $0.0224 \pm 0.0056$ & $0.0079 \pm 0.0038$ & $0.0205 \pm 0.0029$ \\
\hline $\mathrm{COD}_{\mathrm{Mn}} /(\mathrm{mg} / \mathrm{L})$ & $1.3385 \pm 0.4567$ & $0.9385 \pm 0.2503$ & $1.1788 \pm 0.1315$ & $0.9677 \pm 0.0568$ \\
\hline Chl. a/ ( mg/L) & $0.0120 \pm 0.0065$ & $0.0159 \pm 0.0019$ & $0.0073 \pm 0.0032$ & $0.0084 \pm 0.0036$ \\
\hline $\mathrm{pH}$ 值 & $8.29 \pm 0.28$ & $7.84 \pm 0.15$ & $7.71 \pm 0.27$ & $8.06 \pm 0.50$ \\
\hline 水温 $/{ }^{\circ} \mathrm{C}$ & $32.50 \pm 0.45$ & $20.20 \pm 0.46$ & $7.96 \pm 1.53$ & $18.50 \pm 0.58$ \\
\hline $\mathrm{DO} /(\mathrm{mg} / \mathrm{L})$ & $7.95 \pm 0.45$ & $8.06 \pm 0.40$ & - & $9.94 \pm 0.28$ \\
\hline
\end{tabular}

秋季, 轴 1 和轴 2 能反映 $87.9 \%$ 的物种信息量,且影响浮游植物群落结构的主要环境因子是 $\mathrm{PO}_{4}^{3-}-\mathrm{P}^{3}$ 浓 度. 硅藻门的颗粒直链藻最窄变种 (Melosira granulata var. angustissima) 和针状菱形藻 (Nitzschia acicularis) 丰度与 TN、TP 浓度呈正相关, 隐藻门的卵形隐藻 (Cryptomonas ovata) 和尖尾蓝隐藻 (Chroomonas acuta) 丰度 与 $\mathrm{PO}_{4}^{3-}-\mathrm{P}$ 和 $\mathrm{DO}$ 浓度呈正相关, 蓝藻门丰度与 $\mathrm{PO}_{4}^{3-}-\mathrm{P}$ 和 $\mathrm{DO}$ 浓度呈负相关 (图 4).

冬季,轴 1 和轴 2 所能解释的物种比例为 $82.7 \%$, 且影响浮游植物群落结构的主要环境因子为 $\mathrm{PO}_{4}^{3-}-\mathrm{P}$ 和 TP 浓度. 绿藻门的四尾栅藻 (Scenedesmus quadricauda)、土壤绿球藻、镰形纤维藻奇异变种 (Ankistrodesmus falcatus var. mirabilis) 和硅藻门的颗粒直链藻最窄变种丰度与多数环境因子呈正相关,而硅藻门的其它种类 与金藻门的种类受环境因子的影响较小 (图 4).

春季,轴 1 和轴 2 能反映 $91.0 \%$ 的物种信息量,且影响浮游植物群落结构的主要环境因子为 DO 浓度. 春季的大部分优势种丰度都与 $\mathrm{DO} 、 \mathrm{COD}_{\mathrm{Mn}} 、 \mathrm{TP} 、 \mathrm{TN}$ 和 $\mathrm{PO}_{4}^{3-}-\mathrm{P}$ 浓度呈正相关, 与 $\mathrm{NO}_{3}^{-}-\mathrm{N}_{\text {和 }} \mathrm{NH}_{4}^{+}-\mathrm{N}$ 浓度呈负 相关,金藻门的圆筒雉囊藻丰度受环境因子影响较小 (图 4).

综上所述,金沙河水库浮游植物丰度受磷浓度的影响较大.

\section{3 讨论}

\section{1 浮游植物群落结构及演替}

浮游植物季节变化一般规律为: 春、秋季以喜低温的硅藻、金藻为主, 夏季以喜高温的蓝藻、绿藻为主, 冬 

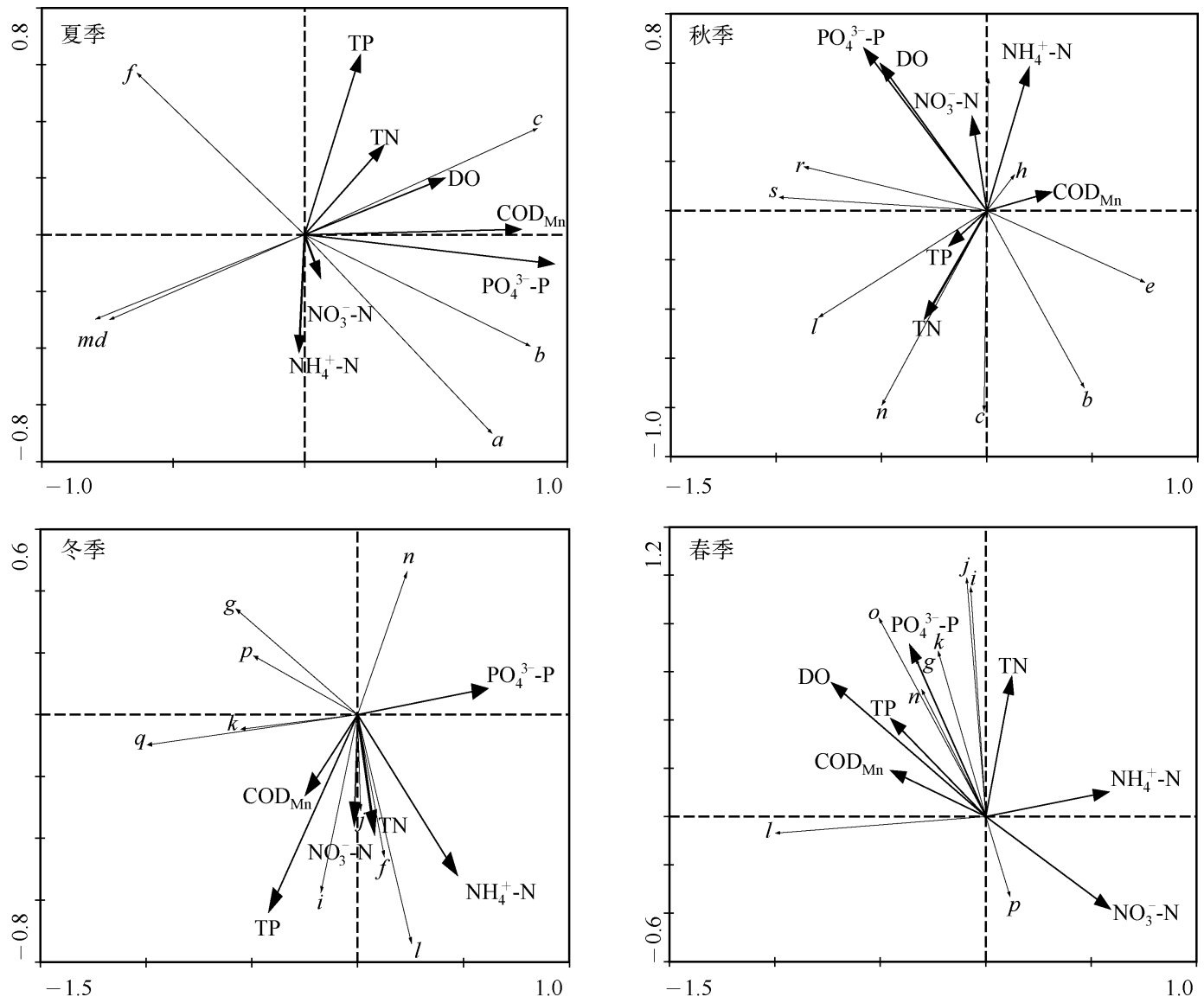

图 4 不同季节物种与环境因子之间关系的 RDA 排序图 ( $a$ : 阿氏颤藻; $b$ : 小胶鞘藻; $c$ : 中华尖头藻; $d$ : 水 华微囊藻; $e$ : 拉氏拟鱼腥藻 (Anabaenopsis racyborskii) ; $f$ : 土壤绿球藻; $g$ : 普通小球藻 (Chlorella vulgaris); $h$ : 漂浮胶丝藻 (Gloeotila pelagica) $; i$ : 四尾栅藻; $j$ : 镰形纤维藻奇异变种 $; ~ k$ : 具星小环藻; $l$ : 颗粒直链藻最 窄变种 $; m$ : 尖针杆藻; $n$ : 针状菱形藻 $; o$ : 链状曲壳藻; $p$ : 圆筒雉囊藻; $q$ : 黄群藻 (Synura urella) $; r$ : 卵形隐 藻; $s$ 尖尾蓝隐藻 $)$

Fig. 4 RDA diagram of phytoplankton dominant species and environmental factors in different seasons

季藻类种类和数量都很少 ${ }^{[5]}$. 金沙河水库浮游植物全年以绿藻门种类最多, 但藻类丰度在各季节的差异比较 大: 夏季呈现蓝藻一硅藻一绿藻型, 秋季呈现蓝藻一绿藻一硅藻一隐藻型, 冬季呈现硅藻一金藻型, 春季转为硅藻型. 这种演替规律与剑潭水库浮游植物演替规律类似 ${ }^{[9]}$, 说明金沙河水库水体夏、秋季污染程度较春、冬季严重.

本研究中, 浮游植物平均丰度为 $111.32 \times 10^{5}$ cells/ L, 平均生物量为 $4.2728 \mathrm{mg} / \mathrm{L}$, 与吕光俊等 ${ }^{[23]} 2006$ 2008 年对金沙河水库浮游植物群落结构研究结果 (丰度为 $123.2 \times 10^{4}$ cells/ $\mathrm{L}$, 生物量为 $1.283 \mathrm{mg} / \mathrm{L}$ ) 相比 明显升高; 另外, 本研究中的 TN 浓度 $(0.6486 \mathrm{mg} / \mathrm{L})$ 和 TP 浓度 $(0.0171 \mathrm{mg} / \mathrm{L})$ 与 2006-2008 年的 TN 浓度 $(0.392 \mathrm{mg} / \mathrm{L})$ 和 TP 浓度 $(0.012 \mathrm{mg} / \mathrm{L})$ 相比也略有升高, 说明金沙河水库水体污染程度有所加剧.

金沙河水库浮游植物优势种随季节变化而变化,夏季以蓝藻门的中华尖头藻 ( 优势度为 0.103 ) 和硅藻 门的尖针杆藻 (优势度为 0.195 ) 的丰度最高, 秋季尖针杆藻消退, 而以蓝藻门的小胶鞘藻 (优势度为 0.180 ) 和中华尖头藻 (优势度为 0.171 ) 丰度最高, 到了冬季, 温度降低, 喜低温的硅藻和金藻大量生长, 硅藻门的 具星小环藻 ( 优势度为 0.220 ) 和金藻门的圆筒雉囊藻 (优势度为 0.234 ) 成为最明显的优势种, 春季温度回 升, 硅藻门羽纹纲的藻类一一链状曲壳藻大量暴发, 其优势度高达 0.910 , 该种在我国大陆地区首次报道后 被确定为广温性种类, 能适应低光强环境, 而且对磷营养的需求相对较低 ${ }^{[24]}$. 该种已被证明广泛分布于浙江 省多个饮用水源水库, 其生态习性可能让其发生较大范围的水华, 从而对水质造成影响 ${ }^{[24]}$. 由此看来, 金沙 
河水库同浙江省多个饮用水源一样,也面临硅藻水华暴发的危险. 因此研究硅藻水华生消机制, 应对水华暴 发的危机,改善水质条件已非常有必要.

\section{2 浮游植物多样性指数}

物种多样性包括组成群落的物种及各物种种群大小或数量, 是生物群落的基本特征之一, 用于评价群落 种类组成的稳定程度、数量分布的均匀程度和群落的异质性 ${ }^{[25]}$. 多样性指数可以表示群落结构的复杂程度, 群 落中生物种类越多, 说明群落复杂程度越高, 对环境的反馈功能越强, 从而使群落结构得到越大的缓冲 ${ }^{[26]}$.

金沙河水库夏、秋、冬季浮游植物 $H^{\prime}$ 和 $D$ 值均较高, 而春季明显较低, 这是因为春季硅藻中的链状曲壳 藻大量暴发, 形成绝对单一的优势种, 使浮游植物物种多样性和均匀度大大降低. 秋季浮游植物的 $H^{\prime}$ 和 $D$ 值 最高, 其 $J$ 值也相对较高, 这是因为秋季没有形成像其它 3 个季节一样的绝对优势种, 藻类分布较均匀, 且其 物种数也是一年中最高的. 冬季浮游植物的 $D$ 值较低, 这是因为冬季温度比较低, 喜温性的蓝藻和绿藻种类 较少. 综合来看, 金沙河水库夏、秋、冬季浮游植物物种 $H^{\prime}$ 和 $J$ 值较高, 春季较低, 而物种 $D$ 值秋季相对较高, 其余季节都较低.

\section{3 浮游植物与环境因子的关系}

浮游植物受很多环境因子的影响. 如 Chl. a 浓度可以基本反映浮游植物生物量大小, 有学者通过测定 Chl. a 浓度得到浮游植物的生物量 ${ }^{[27]}$. 水温也一直被认为是影响浮游植物的主要因素, 它通过影响水生动 植物的新陈代谢, 对水体浮游植物的生长、发育和繁殖产生较大影响 ${ }^{[28]}$; 也有人指出较高 $\mathrm{pH}$ 值 $(8.0$ 以上) 可促进蓝藻的生长 ${ }^{[29]}$.

氮、磷是浮游植物生长繁殖的重要营养盐, 也是常见的限制性营养元素 ${ }^{[30]}$. 在一些淡水水体中氮是影响 浮游植物生长的限制因子 ${ }^{[29]}$, 但水体中的氮来源比较广泛, 部分藻类可以固定大气中分子态的氮气, 弥补水 体氮元素的不足. 因此在水体中磷往往是藻类生长的限制因子, 磷是藻类生长的必需元素之一 ${ }^{[28]}$. 相关文献 指出水体中营养物限制性分类标准为: $\mathrm{TN} / \mathrm{TP} \geqslant 22.6$ (质量比) 为磷限制状态, TN/TP $\leqslant 9.0$ 为氮限制状 态 $^{[31]}$. 金沙河水库 TN/TP 范围为 $33 \sim 43$, 平均值为 38 , 所以金沙河水库为典型的磷限制型营养结构. RDA 分析表明, $\mathrm{PO}_{4}^{3-}-\mathrm{P}$ 浓度是影响金沙河水库浮游植物最重要的水环境因子. 进人水体的磷首先在上层水中被 浮游植物利用, 并且主要利用溶解态无机磷, 同时在其生长中又有大量的磷以磷酸盐形式分泌出来, 藻类死 亡后其尸体中很大一部分磷通过酶的自溶作用以磷酸盐的形式进人水中 ${ }^{[32]}$, 因此藻类的生长、繁殖与磷有 着紧密的联系.

水体中的 DO 一部分来源于大气中, 另一部分来源于水体中浮游植物光合作用所释放的氧气, 浮游植物 通过吸收营养盐来完成光合作用,最终释放氧气, 并使水体中 DO 浓度升高; 而浮游植物死亡时, 有机质的降 解需要消耗水体中的 $\mathrm{DO}^{[33]}$. 因此水体中浮游植物与 $\mathrm{DO}$ 浓度密切相关. 金沙河水库中,夏季蓝藻门的中华 尖头藻丰度与 DO 浓度呈正相关, 因为从夏季一直到秋季, 中华尖头藻一直为优势种类, 其光合作用可以产 生大量的氧, 而水华微囊藻和尖针杆藻夏季丰度较高, 但随着温度的下降, 其在渐渐消亡, 分解需消耗氧气; 秋季主要是蓝藻丰度与 DO 浓度呈负相关, 此时, 温度降低, 大部分蓝藻死亡, 而隐藻丰度上升, 与 DO 浓度 呈正相关; 春季除圆筒锥囊藻丰度与 DO 浓度呈负相关关系外, 其余优势种丰度都与 DO 浓度呈正相关, 此 时因为温度开始回升, 喜低温的金藻也开始消亡.

\section{4 结论}

金沙河水库属于硅藻型水库, 夏季以硅藻门、蓝藻门和绿藻门为主, 秋季以蓝藻门、绿藻门、硅藻门和隐 藻门为主, 冬季则以硅藻门和金藻门为主, 春季硅藻门占绝对优势. 而生物多样性指数显示夏、秋、冬季多样 性较高, 春季多样性显著较低. RDA 分析表明, 影响金沙河水库浮游植物群落结构的主要环境因子为 $\mathrm{PO}_{4}^{3-}-\mathrm{P} 、 \mathrm{TP}$ 和 DO 浓度.

金沙河水库夏、秋季蓝、绿藻较多,有机质含量较高, 并且春季硅藻中的链状曲壳藻大量暴发,有形成硅 藻水华的风险, 所以亟需加强水库水环境保护及周边的污染防治工作, 采取合理措施防止水华大范围暴发, 为红安人民的饮用水源提供安全保障.

致谢: 感谢金沙河水库工作人员在野外采样中提供的帮助! 


\section{5 参考文献}

[ 1 ] 李秋华,韩博平. 基于 CCA 的典型调水水库浮游植物群落动态特征分析. 生态学报,2007,27(6):2355-2364.

[ 2] 叶艳婷, 胡胜华, 王燕燕等. 东湖主要湖区浮游植物群落结构特征及其与环境因子的关系. 安徽农业科学, 2011,39 (23) : 14213-14216.

[ 3 ] Chapman BR, Ferry BW, Ford TW. Phytoplankton communities in water bodies at Dungeness, UK: analysis of seasonal changes in response to environmental factors. Hydrobiologia, 1998, 362: 161-170.

[ 4 ] Rhee GY, Gotham IJ. The effect of environmental factors on phytoplankton growth: temperature and the interactions of temperature with nutrient limitation. Limnology and Oceanography, 1981,26(4) : 635-648.

[ 5 ] 胡鸿钧,魏印心. 中国淡水藻类. 北京:科学出版社,2006.

[6] 刘建康. 东湖生态学研究. 北京:科学出版社, 1990 .

[ 7 ] 刘建康. 东湖生态学研究 (二). 北京:科学出版社,1995:75-91.

[ 8 ] Reynolds CS. What factors influence the species composition of phytoplankton in lakes of different trophic status? Hydrobiologia, 1998, 369/370: 11-26.

[9] 胡 芳, 许振成, 姚玲爱等. 剑潭水库浮游植物群落特征与水环境因子关系研究. 环境科学学报, 2014,34 (4): 950-958

[10 ] Thillai RK, Rajkumar M, Sun J et al. Seasonal variations of phytoplankton diversity in the Coleroon coastal waters, southeast coast of India. Acta Oceanologica Sinica, 2010, 29 ( 5 ) : 97-108.

[11] 李思阳, 韩志勇, 许振成等. 高州水库浮游植物群落结构及其与环境因子的关系. 水生态学杂志, 2013, 34 (5): 16-24.

[12] 盛海燕, 虞左明, 韩轶才等. 亚热带大型河流水库一一富春江水库浮游植物群落结构及其与环境因子的关系. 湖泊 科学, $2010,22(2): 235-243$. DOI 10.18307/2010. 0213 .

[13] 李思阳. 高州水库生态环境评估与水环境因子时空变化特征研究 [学位论文].兰州: 兰州理工大学,2013.

[14] 刘俊利, 熊邦喜, 吕光俊. 金沙河水库鲢、鳙生长特征及起捕规格的研究. 长江流域资源与环境, 2012, 21 (1): 35-39.

[15］曹克驹,冯俊荣,李 静. 金沙河水库乌鳢个体生殖力的研究·水利渔业,1996,1:9-14.

[16］黄道明,林永泰,万成炎. 金沙河水库鲂的年龄与生长. 水利渔业, 1996,5:16-21.

[17] 章宗涉,黄祥飞. 淡水浮游生物研究方法. 北京:科学出版社,1991:333-344.

[18］胡鸿钧,李尧英,魏印心. 中国淡水藻类. 上海:上海科技出版社,1989.

[19] 赵 文. 水生生物学. 北京:中国农业出版社,2005:502.

[20］国家环境保护总局《水和废水监测分析方法》编委会. 水和废水监测分析方法: 第 4 版. 北京: 中国环境科学出版 社, 2002.

[21] 徐兆礼,陈亚篗. 东黄海秋季浮游动物优势种聚集强度.生态学杂志, 1989,8(4):13-15.

[22] ter Braak CJF, Smilauer P. CANOCO reference manual and CanocoDraw for Windows User's guide: Software for Canonical Community Ordination (version 4.5). Microcomputer Power, Ithaca, NY, US, 2002.

[23] 吕光俊, 熊邦喜, 陈 鹏. 华中地区 4 座不同类型水库浮游植物的群落结构和多样性. 中国水产科学, 2012,19(4): 690-699.

[24]马沛明, 施练东, 赵先富等. 一种淡水水华硅藻——链状弯壳藻 (Achnanthidium catenatum). 湖泊科学, 2013,25 (1) : 156-162. DOI 10.18307/2013.0120.

[25] 赵 文. 养殖水域生态学. 北京: 中国农业出版社,2011:91.

[26] 王建国. 西泉眼水库浮游植物群落结构动态特征及其与水环境因子的关系分析 [学位论文]. 哈尔滨: 东北林业大 学, 2011 .

[27] Liu QG, Chen Y, Li JL et al. The food web structure and ecosystem properties of a filter-feeding carps dominated deep reservoir ecosystem. Ecological Modelling, 2007, 203: 279-289.

[28] 郭跃华. 广东省三座大型供水水库浮游植物群落结构动态及其与环境因子的关系 [学位论文]. 广州: 暨南大 学, 2011 .

[29] Temponeras M, Kristiansen J, Moustaka-Gouni M. Seasonal variation in phytoplankton composition and physical-chemical features of shallow Lake Doirani, Macedonia, Greece. Hydrobiologia, 2000, 424(1/2/3): 109-122.

[30] 徐兴华,陈 椽, 宁爱丽等. 阿哈水库浮游植物数量与环境因子的关系. 环境科学, 2012,33(9):6106-6109.

[31] 雷 沛,张 洪,单保庆. 丹江口水库典型人库支流氮磷动态特征研究. 应用生态学报,2011,22(6):3038-3045.

[32] 何志辉.淡水生物学. 北京:中国农业出版社,2000.

[33] 王 刚. 桃山水库水源地浮游植物群落结构特征及水质评价 [学位论文]. 哈尔滨: 东北林业大学,2011. 